\title{
LYKKEN PÅ FØRTIDSPENSION VELFAERDSSTAT OG AFFEKTIV MOBILITET I JENS BLENDSTRUPS GUD TALER UD
}

\begin{abstract}
HAPPINESS ON EARLY RETIREMENT: THE WELFARE STATE AND AFFECTIVE MOBILITY IN JENS BLENDSTRUP'S GUD TALER UD | The article takes its point of departure in current happiness studies and probes the possibly fruitful interdisciplinary relation between research in social science that suggests close links between the Nordic welfare model and the high levels of selfreported happiness we find in the region, and literary criticism which instinctively seems to hold that unhappiness is most conducive to inspire the literary mind. To demonstrate that things are never as simple as that, the article reads Jens Blendstrup's novel, Gud taler ud (2004), as an example of both a welfare narrative and of what it coins "an affective mobility story": a story about a person's enhanced feeling of happiness in retirement. On the one hand, the novel portrays a person who finds happiness when he is granted early retirement from the welfare state. On the other hand, the novel relates this in such a manner that we are reminded that one man's happiness may be another's unhappiness.
\end{abstract}

KEYWORDS I Jens Blendstrup, happiness, fiction, welfare state, affective mobility, old age, early retirement.

Studiet af lykke er et af tidens tegn - ligesom den allestedsnærværende (:) er det. Samfundsvidenskaberne er dybt involveret i udforskningen af såvel objektive som subjektive lykketilstande og af spørgsmålet om, hvordan man bedst måler dem, og filosofien, sociologien, historieforskningen, kulturkritikken og litteraturkritikken gør forsøg på ny-udforskninger af en af vores mest attråede og komplekse følelser, lykkefølelsen. Lykke er blevet et nøgleord, som vandrer mellem disciplinerne og kalder på transdisciplinære analyser. Ikke mindst fordi en række politikere er - eller måske burde være - interesserede $\mathrm{i}$ at ændre fokus fra at måle samfundsmæssige fremskridt alene i forhold til økonomisk vækst og forbrug til at inkludere andre former for vækst, fx i lykke og livskvalitet (Bok). I den situation er det selvsagt vigtigt, vi har en nuanceret forståelse af, hvad lykken er for en størrelse, for som spillet mellem titel og undertitel på Stig Thorsboe og Hanna Lundblads DR tvserie Lykke: en depressionskomedie (2OII-2OI2) indikerer, så rummer lykken ofte indre kompleksiteter.

At lykken ikke er ligetil viser både begrebets historiske foranderlighed (McMahon) og samtidige forståelse hos en række fremtrædende intellektuelle. Filosoffen 
Pascal Bruckner taler om, at en lykkepligt specielt i de vestlige samfund hurtigt bliver en byrde, idet der ikke (længere) er faste normer for, hvad lykken er. Ifølge sociologen Zygmunt Bauman lider vi under den misforståelse, at 'the pursuit of happiness', der om noget har været modernitetens frihedscredo, er blevet forvekslet med en stræben efter penge og forbrug, som beviseligt ikke øger vores lykkefølelse, snarere modsat. Kultur og affektforskeren Sara Ahmed foreslår, at vi er i fare for at blive ulykkelige af det, hun kalder vores lykkeimperativ, der har en tendens til at udelukke retten til at føle anderledes, til $\mathrm{fx}$ at føle sig nedtrykt, deprimeret, 'udmattet' i psykologen Alain Ehrenbergs forstand. Fælles for disse kritiske tænkere og teoretikere er, at de problematiserer det, man kunne kalde det senmodernes lykkenormativitet: det at vi føler os mislykkede, hvis ikke vi er fuldkommen lykkelige hele tiden; det at lykkefølelsen er et problem, som er vores helt eget, og et problem, der kan og skal ordnes nemt og hurtigt med en pille, en selvhjælpsbog og måske en lykkecoach. Med kulturforskeren Raymond Williams kan man sige, at lykkepligten - og de dertil relaterede paradoksale negativitetsfølelser og -stemninger - er udtryk for en hel epokes 'følelsesstruktur' (Williams I28-I35).

Lykkefølelsen er noget, mange samfundsvidenskabelige og sociologiske undersøgelser på forskellig vis prøver at måle både ved simpelt at spørge, hvor lykkelig eller hvor tilfreds med ens tilværelse man er, og ved at holde dette op mod en række andre sociale indikatorer (Greve 28-40). Her viser det sig, at danskerne siger, de er mere lykkelige og tilfredse med tilværelsen end næsten alle andre folkeslag. Danskernes generelt store lykkefølelse dokumenteres i måling efter måling. En undersøgelse fra 2007 udført af den globale pensionsbank HSBC og bearbejdet af Oxford-forskeren G.W. Leeson for ÆldreSagen viser fx, at blandt de lykkelige danskere er personer i alderen 6o-69 år de mest lykkelige, mens personer i gruppen 70-79 år er mere lykkelige end dem i gruppen 40-59 år. 90 \% af gruppen 60-69 år svarer, at de inden for den seneste uge har været lykkelige næsten hele tiden eller det meste af tiden, mens det 'kun' er 78 \% af de 40-49 årige, der svarer tilsvarende. Det får Leeson til at tale om "tilbagetrækningsgevinsten” (24).

Ifølge både amerikanske, svenske og danske velfærdsforskere kan man - til dels - forklare denne høje selvrapporterede lykkefølelse med henvisning til den særlige skandinaviske velfærdsmodels gradvise frigørelse af den enkelte borger fra markedet, som velfærdsstatsforskeren, sociologen Gösta Esping-Andersen betegner som "de-commodification" (dvs. statens relativt generøse økonomiske kompensation for bortfald af arbejdsevne ved sygdom, graviditet, uddannelse, alderdom osv.) (35-54). Flertallets lykke (som jo kan være et mindretals ulykke) synes gjort med denne frigørelse fra markedet i kombination med de nordiske velfærdsstaters udbredte universalitetsprincip om, at alle har samme ret til disse kompensationer, overførsler og services og derfor ikke i så høj grad har grund til at føle sig hhv. stigmatiseret eller som filantropisk herre med ret til at patronisere medborgeren som borgere i andre velfærdssystemer. Universalitetsprincippet hænger igen sammen med den høje grad af tillid, der er i vores samfund såvel borgerne imellem som mellem borgere og samfundsinstitutioner af forskellig art, herunder ikke 
mindst staten, hvilket igen hænger sammen med den lave grad af korruption i Skandinavien (Pacek og Radcliff 2008a; Pacek og Radcliff 2008b; Rothstein 20IO).

Alt dette betyder naturligvis ikke, at alle mennesker er lykkelige i velfærdsstaten; at der ikke er mange danskere, som i stigende grad er utrygge $\mathrm{i}$ forhold til deres pension efter efterlønnens afskaffelse (Hede), er deciderede ulykkelige og fx skærer sig selv (typisk yngre), eller er afhængige af lykkepiller (typisk ældre). I år 2000 kunne Dagbladet Information berette, at en undersøgelse fra Lægemiddelstyrelsen viste, at hver femte kvinde over 85 år var på lykkepiller, hvilket var tre gange så mange som gennemsnittet af befolkningen (Hermansen). I 2007 var tallet steget, så det var hver fjerde (Nielsen). Inspireret af Ehrenbergs undersøgelser af det 'udmattede selv' undersøger psykologen Carsten René Jørgensen bl.a. den veritable depressions-epidemi, vi er vidner til i det senmoderne. Ehrenberg og Jørgensen ser denne som forårsaget af det konstante krav om selvrealisering og det, at den enkelte gøres ansvarlig for at skabe sin egen lykke uafhængigt af tidligere stærke sociale institutioner og samfundsmæssige autoriteter (Jørgensen 43). Depressionsepidemien relaterer sig med andre ord både til en umenneskelig præstationskultur og en offerkultur, hvor den enkelte overlader ansvaret for sit liv til andre instanser end sig selv (44). Danske ældres høje lykkefølelse betyder naturligvis heller ikke, at der er enighed om, hvad der forstås med begrebet lykke, eller at lykkepligten ikke kan være årsag til ulykke og depression. Men det betyder, slet og ret, at rigtig mange danskere over 60 år beretter, at de føler sig lykkelige. Om de så rent faktisk er det eller blot er kulturelt og historisk kodede til at sige det, er en anden sag - en sag for den i forhold til interpersonelle og eksistentielle forhold særligt kompleksitetsindfangende og sensitive skønlitterære forestillingsevne, der næsten per definition stiller sig skeptisk over for ideen om det blot lykkelige menneske.

For så vidt den overhovedet er udtænkt endnu, må en af den litteraturkritiske lykkeforsknings præmisser være det paradoks, at det meste af den moderne litteratur på et eller andet plan handler om lykken og det vellykkede gode liv, men næsten finder sig selv som (seriøs) litteratur ved ikke at kunne indfange netop lykken (Soni). At tænke sig væsentlig litteratur om lykken og et lykkeligt, perfekt, fuldendt liv synes noget sværere end at tænke sig litteratur om det modsatte, om lykkens flygtighed eller umulighed. Litteraturen synes at trives bedst med at tale om tilstanden inden, lykken er opnået, mens den stadig er et håb og en drøm, eller efter den er væk, når vi indser, at vi ikke har den, eller at vi havde den men mistede den. Lykken starter dér, hvor litteraturen slutter, med 'de levede lykkeligt til deres dages ende'. Eller litteraturen foretrækker at tale om, at det, vi troede ville bringe lykken, endte med (også) at bringe ulykke. At tingene med andre ord ikke er så enkle: Det lykkebringende ægteskab den ene roman toner ud med, intonerer som regel starten på samme ulykkelige ægteskab i en anden roman.

Litteraturen synes at have det nemmere med at bore sig ned i de følelseskomplekser, der knytter sig til det melankolske, det sørgelige, det smertefulde, det tragiske, det ubehagelige og væmmelige. Den amerikanske litterat Eric Wilson ser ligefrem en risiko for, at vi udraderer vores evne til at være kreative og skabe 
stor kunst i og med det enorme konsum af lykkepiller, som specielt amerikanske forbrugere har, for så vidt litteraturen næres både af traditionelt ophøjede følelser som melankoli og sublimitet, og de små 'grimme' hverdagsfølelser, Sianne Ngai behandler. Wilson beskriver et skrækscenarie, hvor diverse psykofarmaka har udryddet al menneskelig melankoli: "Vi er muligvis ikke langt fra at udrydde en stor kulturel kraft, en afgørende inspiration til innovation, musen bag megen kunst og digtning og musik. Hensynsløst higer vi efter at rydde verden for talrige ideer og visioner, mangfoldige innovationer og meditationer. Vi er i dette øjeblik i gang med at udrydde melankoli” (4). Den rene lykke er ikke nødvendigvis den rene lykke.

Den danske forfatter og multikunstner Jens Blendstrups (f. I968) værk kredser netop centralt om lykken i dens moderne former. Han har fx sammen med fotografen Lars Gundersen udgivet Toverelses med lykkelig udgang (2008), og hans novellesamling Pludselig flaben (2007) er præget af et skriggult omslag med smiley. Men han er ikke uden blik for, at der i den tilsyneladende lykke kan gemme sig noget dæmonisk. Det bringer han frem i den korte roman Gud taler ud (2004), som er et hovedværk i den nyere danske litteratur. Blendstrups roman betegnes eksplicit som 'roman', dvs. som fiktion, men den er meget tæt knyttet til Blendstrups egen familiehistorie centreret omkring farens historie. Men for at kunne skrive romanen måtte faren omtales som Gud, hvilket om noget transformerer det faktuelle liv til fiktiv fortælling. Romanen fortæller om et unikt menneskeliv, som i hvert fald romanens fortæller, sønnen Jens, udlægger som tilsyneladende lykkeligt. Lykkeligt på trods - eller måske i kraft - af alskens modgang og ulykke og vanvid, forfald og dødelighed. Lykkeligt, på en næsten pervers vis, både på trods af og i kraft af den i romanen ikke nærmere diagnosticerede sindslidelse, der gjorde, at Gud blev førtidspensioneret og fik muligheden for at realisere sig selv og finde sin egen lykke i livet efter arbejdslivet.

Gud taler ud kan med andre ord læses som eksempel på en kunstnerisk artikuleret opdagelse af en ny tilværelsesform med nye værdier, holdninger og prioriteringer og nye følelser ikke mindst - som er dukket frem i og med de bedre og bedre muligheder for offentligt finansieret tilbagetrækning, velfærdsstaten i stigende grad har tilbudt, særligt de sidste godt 50 år. Fordi den således er formet af velfærdsstaten i sin sociale imagination er romanen en eksemplarisk 'velfærdsfortælling', der bidrager med særlig viden om tilværelsen i velfærdsstatens tid (Hansen 20Io). Blendstrups roman er som velfærdsfortælling ydermere et eksempel på noget, jeg kalder affektiv mobilitet. ${ }^{\text {I }}$ Affektiv mobilitet er som forestilling og begreb tænkt som pendant til social mobilitet med en forskydning $\mathrm{i}$ fokus fra de ydre socioøkonomiske omstændigheder til de indre følelsesmæssige og affektive omstændigheder omkring den velfærdsstatslige tilværelse. Velfærdsstaten ønsker at øge

I Dette behandles mere indgående og med inddragelse af Kirsten Thorup, Christian Jungersen, Anders Bodelsen, Henning Mortensen, Jacob Berner Moe, Bent Vinn Nielsen, Aase Schmidt, Trisse Gejl, Bent Haller m.fl. i Peter Simonsen, Livslange liv: Plejehjemsromaner og pensionsfortallinger fra velfardsstaten (fortkommende). 
yngre generationers sociale og økonomiske mobilitet for at sikre lighed og vækst, og ligeledes ønsker den at sikre ældre generationer mod uværdig social nedstigen eller de-mobilitet. Mobiliteten forskyder sig for pensionisten til et affektivt plan, hvor opstigningen typisk findes i graden og måske intensiteten af lykkefølelsen, oplevelsen af livskvalitet eller følelsen af tilfredshed med tilværelsen, sådan som fx Leesons undersøgelse dokumenterer, er tilfældet for flertallet af danskere over 60 år, der oplever "tilbagetrækningsgevinsten” (Leeson 24) på samme måde, som Gud gør det i Blendstrups roman.

Gud taler ud fortæller som sagt på en særegen måde om faren, der omtales som Gud. Tekstens særlige måde at fungere på indrammes af titlens paradoks: ideen om, at det er Gud snarere end mennesket, der 'taler ud' i forstanden går til bekendelse og beretter om intime, hidtil skjulte sandheder (Borup). Her genereres også tekstens særlige humor, idet de ting, Gud taler ud om, og de ting, han gør, konsekvent er ikke-gudelige. Det er fx ikke særligt guddommeligt at blive førtidspensioneret, fordi man ikke magter sit job, hvilket netop sker for Uffe Blendstrup, som er Guds og forfatteren og fortælleren Jens Blendstrups biologiske fars borgerlige navn. I teksten antydes det, at han bliver pensioneret, da han begynder at gøre mere skade end gavn på sit arbejde som psykolog:

"Gud venter på pensionen. Det drejer sig om dage nu. Der er sket det heldige at Gud har fået førtidspension. Uden at være døende eller lemlæstet. Han har studeret femten år og arbejdet femten. Nu må det være nok. Ikke fordi Gud ikke har været dygtig. Gud har skrevet interessante psykologiske artikler og hjulpet mennesker på sin vej. Men Gud er ikke et menneske som kan slippe sine patienter. Han bærer dem ligesom med sig hvor han går. Og over årene er det blevet til mange mennesker der sådan er kommet ind i Guds billede og blevet der i form af sår, som Gud kalder det når han skal være nænsom. For dybest set er Guds kærlighed ret stor. Han kan bare kun vise den i serier. Og patienter der lider, skal jo have det meste af Guds kærlighed, al den stund at Gud er ansat til at hjælpe disse patienter. Hvorfor Guds egen familie må tildeles lidt færre kærligheds-serier”. (39)

Underdrivelsen "lidt færre" gemmer de mange fysiske, verbale og psykiske omsorgssvigt, faren tildelte sin familie. I et interview med Carsten Andersen taler Blendstrup om at være blokeret af at skulle sige Uff eller far og om, hvordan det at omtale ham som Gud blev løsningen på skriveblokeringen. Blendstrup siger, at han som syttenårig lovede faren at skrive bogen, men at han er glad for at have ventet til nu, da bogen ellers ville være blevet et rent helteportræt. I stedet er nye mere smertelige erkendelser gjort i selve skrivningen, der tog sit udgangspunkt i voldsom affekt, som Blendstrup udtrykker det i interviewet:

"[Jens Blendstrup] siger selv, at han har skrevet Gud taler ud på lykkepiller, som han fik for det, han kalder en stressbetinget depression i forlængelse af faderens død.

'Jeg tudede i et par uger, og så gik jeg til psykiater. Jeg gik med vilje ikke til 
psykolog, for min far var jo psykolog, og jeg har altid været god til at svare rigtigt til psykologer. Faktisk frarådede psykiateren mig at skrive bogen, fordi jeg efter hans mening befandt mig i en slags undtagelsestilstand'.

Jens Blendstrup valgte at overhøre det velmente råd. Han ville skrive bogen om sin afdøde far, og undervejs har han ikke et sekund spekuleret over, om andre end ham selv og hans familie kunne være interesseret i historien om Uffe fra Risskov. Og først bagefter er det gået op for ham, at historien om Gud er blevet noget mere brutal, end han havde forestillet sig.

'Jeg ville gerne prøve at forstå ham, for det er jo let nok at være søn og dyrke sin far, men når man er forfatter, får man nogle gange noget at vide ved at skrive. Han er blevet tydeligere for mig. Jeg har for eksempel aldrig tidligere tænkt på ham som alkoholiker', siger Jens Blendstrup”. (Andersen)

Hvis det er sandt, at Blendstrup skrev på lykkepiller, har Wilson måske ikke så stor grund til bekymring over, om lykkepillerne udraderer menneskelig kreativitet, for så vidt benævnelsen og skabelsen af Gud i denne roman er et prægnant højdepunkt i nyere dansk litteratur. Og det er et udslag af Blendstrups mageløst morsomme fantasi at lade Gud være en udbrændt og forkælet psykolog, der ikke kan slippe sine patienter. Gud bliver syg af dem, han skulle hjælpe i den udvidede familie, velfærdsstaten gerne præsenterer sig som, fordi han ikke kan kontrollere sin altomfavnende kærlighed, alt i mens han som kompensation i stigende grad tyranniserer sin egen familie.

Meget af det, Gud gør derhjemme, er grusomt og traumatisk på trods - og delvist i kraft - af tekstens overvejende humoristisk affejende stil. Humoren er dog ikke karakteristisk for et afsnit som det, hvor Gud kommer hjem fra arbejde i "den sidste hårde tid før pensionen” (35) og moren må låse de yngste børn på seks og otte år inde på værelset, hvor "den næstyngste tager tid på et gammelt vækkeur, om to minutter, Jens. Skal vi vædde på han er her om to minutter. Og ganske rigtigt pludselig kobler Gud en skævt placeret vase med sine børn, og så er de jo skarnsunger, og så skal de straffes, og Gud tager i håndtaget og brøler, Luk så op” (35-6). Denne gammeltestamentligt skræmmende passage gøres ekstra skræmmende gennem den autofiktive brug af forfatterens navn, Jens, til at betegne den yngste og antageligvis mest angste søn. Fiktionens slør brydes her, og teksten opnår en gysende virkelighedseffekt. Gennem bl.a. denne indskrivning af det biografiske subjekt opnår Blendstrup en særlig grad af autenticitet i skildringen af faren og det, som er tekstens hovedærinde ud fra en læsning af den som realistisk velfærdsfortælling: at forstå faren ved at skildre den transformation og affektive mobilitet, han oplever i forbindelse med statens kompenserende og aflastende intervention i den dysfunktionelle familie i form af tildelingen af førtidspensionen. Men på samme tid er omtalen af faren som Gud snarere end Uffe (kan man tænke sig et mere realistisk romannavn, der samtidig ville have rummet en tung symbolik på 'uf) gennemført de-naturaliserende og noget, der også og samtidig suspenderer denne virkelighedseffekt og indføjer en gennemgribende tvivl og skeptisk følelse 
i læseren, hvad angår oprigtigheden af hele bogens projekt om at skildre faren indefra.

Jo nærmere pensionen kommer, jo mere harmonisk og menneskelig bliver Gud. Han beklager sågar sine fejl over for sønnerne, og hans epilepsi aftager (39). Guds førtidspensionering tillader ham en ny start:

"Det er som om den første tid her er svær. Gud tager mål af mørkets dybde, og det bekymrer ham at det ikke er dybere. Det bekymrer ham at mørket ikke længere er forbeholdt weekenderne men i praksis alt. Hvilket jo er en devaluering. Gud må gøre noget. Og langsomt går han over mod kanten, drevet af sit Gudeinstinkt. Endnu er det ikke det store. Men Gud er dog på vej mod kanten, som en lærd mand der lægger lærdommen bag sig og langsomt begynder at tromme”. (4I)

Blendstrup billedliggør starten på pensionistlivet som Gud, der bevæger sig mod det klassiske topos for overskridelse og sublim erkendelse, afgrundens kant, konfronterer mørket og med et dunkelt billede langsomt begynder at tromme. Det fanger præcist det typiske og dybt rituelle ved pensionssituationen (trommen som rituelt instrument), som er en overgangsituation eller indvielsesrite (markeret ved billedet af afgrunden), der tager en person ind i det ukendte, i særdeleshed i det senmoderne, hvor der ikke er fastlagte og traditionsoverleverede normer for adfærden som pensionist, men hvor man selv forventes at skabe dem med både store emancipatoriske løfter og stressbefængte kriser til følge. Gud affører sig sin hidtidige identitetskappe (lærdommen og fornuften) og vender sig mod noget andet (den kropslige, rytmiske trommen).

Efter dette poetisk højstemte moment fortsætter teksten kontrapunktisk med prosaiske indslag om, at Gud skraber sne og påtænker at skrive en roman, førend den nyfundne frihedsfølelse, der knytter sig til pensioneringen, har sat sig:

"Uden Gud har kæmpet meget er han begyndt at slappe af. Og uden Gud har gjort det store er han begyndt at falde ind i sit nye liv. Han står og pisser på rabarberne og kan ikke lade være med at le. Der står han med benene solidt plantet i det grønne græs og har masser af år tilbage. Og ingen af dem skal tilbringes bag lukkede døre. Aldrig mere skal han skrive journaler. Aldrig skal han lide af søvnløshed uden at kunne sove. Han kan sove til klokken tolv hvis han vil. Han kan træde i karakter og antage en større skygge”. (44)

Gud er fritaget for sit ansvar for patienterne og for sin vrede på familien. Gud kan blive sig selv - endelig realisere sig selv og træde i karakter.

Blendstrups roman er kort og stramt komponeret i en række kompakte, visuelt fokuserede tableaux, der nok tilsammen fortæller en historie, men er uden noget særlig komplekst plot og uden en borende psykologisk interesse. Man kan sige, at fraværet af dette næsten er suspekt, som om det hele ville blive for meget, hvis der så meget som blev lettet på det psykologiserende låg. Et enkelt sted hedder det, 
at Gud senere skulle komme til at høre meget for sin opførsel (35), men opførslen analyseres aldrig af sønnen som psykologisk fænomen. Det ville være farens gebet, som tydeligvis ikke forbindes med løsninger i dette fiktive univers, hvor der heller ikke moraliseres over farens gøren og laden, for hvem kan fælde moralske domme over Gud? Der berettes, visualiseres og gives nærmest nøgternt og meget stiliseret vidnesbyrd. Humoren synes betinget af de mange korte læsepauser mellem scenerne, og det ville være ubærligt med en mere traditionel roman med Gud som hovedperson og det opskruede tempo og den megen slapstickagtige situationskomedie. De mange læsepauser tillader, at det, man kunne kalde tekstens grundfølelse eller -stemning, artikuleres som en stigende undren over misforholdet mellem det utålelige, faren gør, og omgivelsernes tilsyneladende tilbedende accept af ham. Det er et misforhold, der også er på spil i tekstens udsigelse, hvor sønnen ofte giver indtryk af at vide præcist, hvad faren tænker og føler, samtidig med at sønnen må omtale faren som Gud, dvs. som en for mennesket i traditionel forstand nærmest ufattelig størrelse. Der er både en ligefrem nærhed og virkelighedsfornemmelse i sønnens kærlige fortælling, og en stiliseret distance dels i kraft af udsigelsen, dels i kraft af betoningen af humoristisk situationskomedie over psykologisk analyse. Denne distance suspenderer aldrig helt kærlighedserklæringen, men holder den i udstrakt arm, så den kan håndteres i al sin modstridende kompleksitet.

På et tidspunkt får Gud konstateret kræft, og teksten bevæger sig fra en rablende humoristisk fremstilling af de ting, han gør med sin nye frihed, til en mere dyster, men stadig morsom historie om forfaldet og dødens komme (se fx meditation om hænder og dødelighed (Io6)) og forberedelserne dertil (fx de tre testamenter, han forfatter (III)). Efter beskeden fra lægerne om, at han har to år tilbage pga. kræften (II5), bliver teksten nærmest en slags patogenese med stor sans for præcise detaljer. Men selv - netop - i fremskreden alder (han er blevet 74 år) med døden så tæt på, er der øjeblikke af fuldkommen lykke for førtidspensionisten (der jo nu er fuldgyldig folkepensionist). Bedst udtrykt i hvad der må betegnes som romanens klimaks som affektiv mobilitetshistorie i form af sønnens indlevede beskrivelse af den varme dag i august, hvor Gud går tur ved stranden med sin trofaste skygge, den nu halvblinde affældige hund Schenko, som han købte efter pensioneringen, og som blev hans faste følgesvend i pensionistlivet. Schenko skaber et guddommeligt kaos og virvar blandt de solbadende mennesker:

"Hvad er det der ligger der mellem de der ben? tænker Schenko. Og snuser til en 40-årig kontorassistent der hviner. Nej, det er kraftedme for ulækkert, råber hendes mand. Hvem ejer den ulækre hund der? Hvem ejer den? Men Gud giver sig ikke til kende. Han er så lykkelig så lykkelig. For hunden laver jo rav i den. Og det er da en hunde-ret at daske rundt og forstyrre og bryde ind i alle stakkels skrøbelige eksistenser hvis sjæle blafrer som presenninger i vinden, det ville han da også gøre hvis han havde været hund og ikke en førtidspensioneret psykolog med dæmoniske pligter. Og de kan da bare lade være med at skrige og prøve at vifte Schenko væk, for hunden tror jo det er en leg så, og så er det han begynder at grave huller 
og nappe damen bagi. Hvilket får Gud til lige så stille at gå op og gemme sig i en hybenbusk for det er dog en bedre position til hundens anfald. Åh, ler Gud. Da Schenko løber ned til havet og henter sit ådsel og kommer tilbage og smider det på menneskenes rene tæppe. Mit halvblinde monster, klukler Gud og suger dybt ind i sin cigaret. Dette sceneri. Damens fisse. Mandens blodtryk. Middelmådige mennesker mod en overjordisk hund der er gået i selvsving”. (I2O-I)

I dette tableau fremmanes den sansetunge varme sommers lys, dufte og lyde. Det kaos, hunden skaber, indfanges i de lynhurtige synsvinkelskift, citatet indledes med, mellem hunden, den sure badegæst og Gud ved stranden. Denne scene, hvor man nærmest kan sige, at Gud gennem sønnens empatiske fantasi betragter sit skaberværk og er tilfreds - den affektive mobilitet i form af den sprudlende lykkefølelse dobbelteksponeres og benævnes eksplicit: "så lykkelig så lykkelig” - er begyndelsen på enden for den kræftsyge far, som udefra og objektivt set ikke burde være lykkelig, idet han nu er i hastigt forfald pga. kræften, men som indefra og subjektivt set tolkes som lykkelig.

Affektteoretisk ligger der en pointe $i$ at opholde sig ved hele problematikken omkring synsvinkel og medsyn, der betones i denne passage og romanen som sådan. På den ene side er det, som om fortælleren Jens har fuldkomment indblik i farens inderste følelsesliv og kan tale frit og oprigtigt om det. Her hører vi virkelig, hvordan det i den givne situation føles at blive gammel og syg for dette virkelige menneske af kød og blod. Gengivelsen af følelserne er direkte. På den anden side er denne passage og hele romanen gennemstiliseret og kunstig. For at skrive den må Jens kalde faren for Gud. En mere gennem-fiktiv og kunstig gestus kan vel nærmest ikke tænkes. Og for at skrive ovenciterede passage må han bilde os ind, at det ikke blot er Gud, han kan føle sig helt ind i (og hvem kan dog det), men også hunden Schenko, som vi ret beset, faktuelt, ikke ved hvordan opfatter verden, hvad den tænker om noget som helst. Med andre ord, der er både et postulat om, at lykkefølelsen er oprigtig og autentisk, og at den er iscenesat, konstrueret, villet og tænkt, dvs. ikke følt spontant.

Blendstrup viser stor indlevelse $\mathrm{i}$ og forståelse for, hvad det kan indebære at blive pensioneret og ældes, blive fri for arbejde og kunne nyde sin fritid, samtidig med at man modvilligt men med stoisk ro og sand galgenhumor nærmer sig forfaldet til afhængighed af andres pleje og omsorg. Indirekte viser han en velfærdsstat, der fungerer på traditionel vis ved at yde kompensation for den sociale begivenhed, det er at miste arbejdsevnen og forsørgerevnen inden folkepensionsalderen og derfor måtte overgå til passiv offentlig forsørgelse "Uden at være døende eller lemlæstet", som det hedder i en allerede citeret passage (39). Førtidspensionen gør, at familien kan blive boende, og tabet af arbejdsevne resulterer ikke i en social katastrofe: der er dækning for indkomstbortfaldet. Og familien behøver ikke ramme bunden i endeløs ruin, før overførslerne kan begynde: i en uforglemmelig scene har Gud råd til at tage toget til København og betale sønnens Statens Uddannelsesstøttes lån tilbage: 75.000 kr. i kontanter 
fragtes til København i en kuffert og afleveres på kontoret, selvom systemet ikke engang er begyndt at opkræve afdrag:

"Bagefter står de lidt på gaden. En god følelse ikke søn? Jo svarer Guds yngste. Cigar? siger Gud. Caminante? Nu er du sådan set fri til at bedrive idiotiske digte. Vi kunne måske starte med noget røget ål? Jeg giver, hoverer Gud og finder et bundt hundredkronesedler frem fra cottoncoatens inderlomme. Hvor meget var det du fik for dit speciale? 6. Det er en udmærket karakter, siger Gud. Man skal heller ikke lefle. Jeg er stolt af dig, min dreng”. (IOo)

Vi ser en velfærdsstat, som sikrer en værdig pensionisttilværelse, alderdom og død for den enkelte og den familie, som nok ville være for svag til at kunne klare sig selv. Samtidig stiller staten sig heller ikke i vejen for den anarkistiske enspænder, der, som ovenfor, bryder normerne og slår sig op som gammeldags mæcen for sønnen - på sin vis muliggør og bestiller denne tekst.

Vi ser en velfærdsstat, der giver lykkens og dermed den affektive mobilitets mulighedsbetingelse - ikke lykken selv. Skæbnens ironi og det, at der er en skønlitterær historie, som er værd at berette, vil så, at det drejer sig om en person, der pensioneres, fordi han er for ulykkesbringende og (selv)destruktiv, selv om han som profession - psykolog på et offentligt hospital - er en vigtig del af velfærdsstatens sociale kriseberedskab; at lykken tilskrives en person, omgivelserne ville diagnosticere som ulykkelig, og som vi aldrig kan være sikker på rent faktisk er genuint lykkelig andre steder end i sønnens fantasi. En person hvis egen, egoistiske lykke synes at være betinget af og også at medføre andre fællesskabers ulykke, både familiens og de uskyldige badegæsters. Blendstrups umiddelbare ærinde i Gud taler $u d$ synes at forme sig som en søns forsøg på at skrive om kærligheden til den far, der havde den men aldrig gjorde sig fortjent til den. I stedet var faren ansvarlig for serielt omsorgssvigt, som sønnen måske først erkender i skriveprocessen og registrerer i måden at benævne faren på og i hele stiliseringen i de korte slapstickmorsomme, men også grusomme tableaux. I og med dette kommer Blendstrup til på dybt original vis at gennemlyse velfærdsstaten og vise nogle af dens affektive tilstande, bl.a. evnen til at kunne forestille sig det privilegium at finde lykken i et sceneri som det ved stranden, hvor den gamle halvblinde hund terroriserer menneskene på stranden, mens Gud klukler - dvs. evnen til samtidigt at fremstille lykken som autentisk og dybtfølt og som kunstig og iscenesat.

\section{LITTERATURLISTE}

Ahmed, Sara. The Promise of Happiness. Durham og London: Duke University Press, 2010.

Andersen, Carsten. "Guds søn taler ud”. Politiken 24. november 2004. Infomedia artikel-id: eo2c2eo8. Bauman, Zygmunt. The Art of Life. Cambridge: Polity Press, 2008. 
Blendstrup, Jens. Gud taler ud. 2. udgave. (2004). København: Samleren/Rosinante, 2008.

Bok, Derek. The Politics of Happiness: What Government Can Learn from the New Research on Well-Being. Princeton og Oxford: Princeton University Press, 2009.

Borup, Anne. 'Tekstens interaktionsrum - tekst, kontekst, paratekst. Om Jens Blendstrups roman Gud taler ud". Spring 28 (2009): 67-84.

Bruckner, Pascal. Perpetual Euphoria: On the Duty to be Happy. Overs. Steven Rendall fra L'Euphorie perpétuelle: Essai sur le devoir de Bonheur (2000). Princeton og Oxford: Oxford University Press, 2 ого.

Ehrenberg, Alain. Det udmattede selv: Depression og samfund. Overs. Peer F. Bundgaard fra La fatigue d'être soi: Dépression et société (1998). København: Informations Forlag, 2010.

Esping-Andersen, Gösta. The Three Worlds of Welfare Capitalism. Princeton, NJ: Princeton UP, I990.

Greve, Bent. Et lykkeligt land? Hvad skal der til og kan velfardssamfundet bidrage? Frederiksberg: Nyt fra samfundsvidenskaberne, 2010.

Hansen, Nils Gunder. Velfardsfortallinger: Om dansk litteratur i velfardsstatens tid. København: Gyldendal, 2010.

Hede, Anders, Jørgen Goul Andersen og Jacob Andersen. Tryghedsmåling 20II: Danskers tryghed $i$ krisens ar 3. Trygfonden. 7. februar 2013. http://www.e-pages.dk/trygfonden/147/65.

Hermansen, Line Grove. "Hver femte ældre er på lykkepiller". Information I8. november 2000. Infomedia artikel-id: YoI34050.

Jørgensen, Carsten René. Danmark på briksen: Et psykologisk perspektiv på Danmark og danskerne i det senmoderne. København: Hans Reitzels Forlag, 20II.

Leeson, George W. Fremtidens Aldre. Danmark. Resultaterne fra HSBC's Global Survey Future of

Retirement. University of Oxford: Oxford Institute of Ageing, 2008.

McMahon, Darrin M. Happiness: A History. New York: Atlantic Monthly Press, 2006.

Ngai, Sianne. Ugly Feelings. Cambridge, MA og London: Harvard University Press, 2005.

Nielsen, Line Holm. ”Hver fjerde ældre får antidepressiv medicin”. Berlingske Tidende 26. maj 2007. Infomedia artikel-id: eogc $7 \mathrm{bc5}$.

Pacek, Alexander og Benjamin Radcliff. "Assessing the Welfare State: The Politics of Happiness". Perspectives on Politics 6, 2 (2008): 267-277.

Pacek, Alexander og Benjamin Radcliff. "Welfare Policy and Subjective Well-Being Across Nations: An Individual-Level Assessment". Social Indicators Research 89 (2008): I79-I9I.

Rothstein, Bo. "Happiness and the Welfare State". Social Research 77, 2 (2010): 44I-468.

Soni, Vivasvan. Mourning Happiness: Narrative and the Politics of Modernity. Ithaca: Cornell University Press, 20Iо.

Williams, Raymond. Marxism and Literature. Oxford: Oxford University Press, 1977.

Wilson, Eric. Against Happiness: In Praise of Melancholy. New York: Sarah Crichton Books/Farrar, Straus and Giroux, 2008. 